\title{
Experimental Study on Effects of Type and Replacement Ratio of Fly Ash on Strength and Durability of Concrete
}

\author{
Hongzhu Quan ${ }^{1, *}$ and Hideo Kasami ${ }^{2}$ \\ ${ }^{1}$ School of Civil Engineering, Qingdao Agricultural University, Qingdao, Shandong, 266109, China \\ ${ }^{2}$ Japan Association for Building Research Promotion, Tokyo, 108-0014, Japan
}

\begin{abstract}
This paper presents the test results of a series of experimental studies on the effects of type and replacement ratio of fly ash on strength and durability of concrete. 3 types of fly ashes are used in this research, the specific surface area of which are $5070 \mathrm{~cm}^{2} / \mathrm{g}, 3760 \mathrm{~cm}^{2} / \mathrm{g}$ and $1970 \mathrm{~cm}^{2} / \mathrm{g}$, respectively. They satisfy the requirement of Type-1, Type-2 and Type-4 fly ashes in Japanese Industrial Standard. Ordinary Portland cement, river sand, crushed sandstone, water reducer and air entraining agent are used as well. The results indicate that drying shrinkage of concrete is reduced when cement is partially replaced by fly ash. Comparatively, Type-2 fly ash's addition leads to a more effective drying shrinkage reduction, and those with replacement ratios result in larger dry shrinkage reduction. Carbonation increases with the increase of replacement ratio of fly ash, and concrete with Type- 1 fly ash has higher carbonation than those with Type- 2 and Type- 4 fly ashes. The carbonation rate is found to be linear with water cement ratio regardless of replacement ratio of fly ash. Durability factor decreases with the replacement ratio of fly ash after 300 freezing and thawing cycles. Also, durability factor of concrete containing Type- 1 and Type- 2 fly ashes with replacement ratio of $25 \%$ to $55 \%$ is higher than $80 \%$. However, those with Type-4 fly ash show lower durability factor after 300 cycles. Concretes with $70 \%$ replacement of fly ash are not durable in spite of the type of fly ash or specific surface area.
\end{abstract}

Keywords: Carbonation, Compressive strength, Drying shrinkage, Fly ash, Freezing and thawing, Replacement ratio.

\section{INTRODUCTION}

Fly ash in Japan has been rapidly increasing with the increase of coal-fired power stations. The annual production of fly ash is 10 million tons [1]. Though approximately $80 \%$ of fly ashes are utilized mainly in cement industries, only $2.4 \%$ of fly ash is used as admixture material for concrete, including composite cement and concrete. In addition, more and more ground granulated blast-furnace slag is used in concrete partially replacing cement for the purpose of reducing material costs and avoiding cracks in mass concrete. Furthermore, the addition of such kinds of supplementary cementitious materials can reduce the risk of alkali-aggregate reaction, and reduces $\mathrm{CO}_{2}$ emission. The obstacles preventing fly ash utilization in Japan are that the permissible replacement ratio of fly ash is limited to $30 \%$ for structural concrete, and that only Type- 1 and Type-2 fly ashes are usually specified, while JIS A 6201 Japanese Industrial Standard for Fly Ash Used in Conrete specifies Type-1, Type-2, Type-3, and Type-4 fly ashes. For instance, JIS R 5213 Japanese Industrial Standard for Fly Ash Cements requires that the portion of fly ash in the cementitious material is limited to $30 \%$ by mass. Japanese Architectural Standard Specification JASS 5 for Reinforced Concrete Work requires

*Address correspondence to this author at the School of Civil Engineering, Qingdao Agricultural University, Qingdao, Shandong, 266109, China; Tel: +86-532-88030416; +86-13792443322; Fax: +86-532-88030411; E-mail:quanhz719@yahoo.com.cn the permissible Portland cement replacement with Type-1 and Type- 2 fly ash is limited to $30 \%$ by mass, and JASS $5 \mathrm{~N}$ for Reinforced Concrete Work at Nuclear Power Plants requires that the cement replacement should not more than $20 \%$ by mass. Therefore, it is necessary to clarify the influence of type and replacement ratio of fly ash on the strength and durability of concrete in which cement is replaced by higher volume of fly ash, so as to expand the application field of fly ash.

At present, the utilization of fly ash in Japan is defined in Type- 1 and Type- 2 fly ashes, and the replacement ratio is limited to $30 \%$ for structural concrete. In order to expand the application range of fly ash in structural concrete, the Type-1, Type-2, and Type- 4 fly ashes are taken as research object in this study, and the replacement ratio increases to $70 \%$. Meanwhile, the effects of type and replacement ratio of fly ash on mixture proportions, fresh concrete properties, strength development, drying shrinkage, carbonation and freezing-thawing resistance of concrete are widely discussed.

\section{SCOPE OF EXPERIMENT}

5 mixtures of ordinary Portland cement (OPC) concrete, of which the water cement ratio is from $38 \%$ to $75 \%$, are designed as reference specimen. 28 mixtures of fly ash concrete with the water binder ratio from $38 \%$ to $60 \%$ are used to test the compressive strength, drying shrinkage, carbonation and freezing and thawing resistance, where Portland 
cement is replaced by 3 types of fly ashes by ratios from $25 \%$ to $70 \%$.

\section{MATERIALS}

Type-1 fly ash (FA1), Type-2 fly ash (FA2) and Type-4 fly ash (FA4), from a coal-fired power plant are used. All the indexes satisfy the requirements of JIS A 6201 Japanese Industrial Standard for Fly Ash Used in Conrete. Chemical analysis and physical characteristics of fly ashes are shown in Table 1. Scanning electron micrographs of fly ashes are shown in Fig. (1). The differences among 3 fly ashes are mainly in particle size. The specific surface area of FA1, FA2 and FA4 are $5070 \mathrm{~cm}^{2} / \mathrm{g}, 3760 \mathrm{~cm}^{2} / \mathrm{g}$ and $1970 \mathrm{~cm}^{2} / \mathrm{g}$, respectively.

Ordinary Portland cement with density of $3.16 \mathrm{~g} / \mathrm{cm}^{3}$, specific surface area of $3280 \mathrm{~cm}^{2} / \mathrm{g}$ and 28 days compressive strength of $62.0 \mathrm{~N} / \mathrm{mm}^{2}$ is used. The coarse aggregate is a kind of crushed sandstone from Oume, and the fine aggregate is a kind of river sand from Oui-River. The physical properties of aggregates are shown in Table $\mathbf{2}$. The water reducer used in this research is of lignosulphonic acid type, and the air-entraining agent of anionic surfactant is used in this research.

\section{MIXTURE PROPORTIONS AND DOSAGE OF AE AGENT}

Mixture proportions of concretes are shown in Table 3. The target slump is $18.0 \mathrm{~cm}$, and the target air content is $4.5 \%$.

Water content of concrete containing FA1 and FA2 decreases with the increase of fly ash dosage, while water content of concrete increases with the addition of FA4. Air-

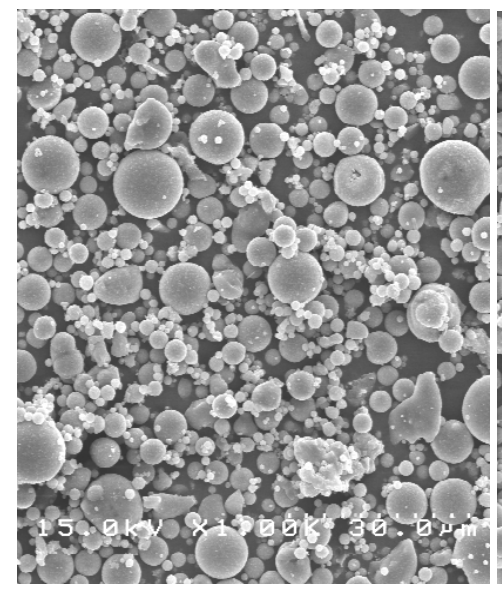

FA 1

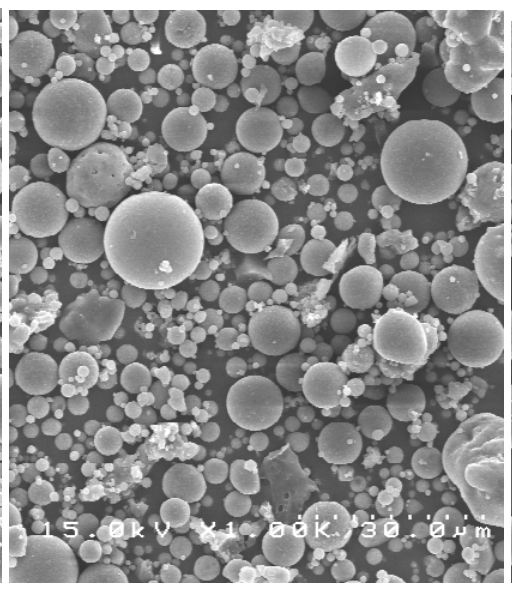

FA 2

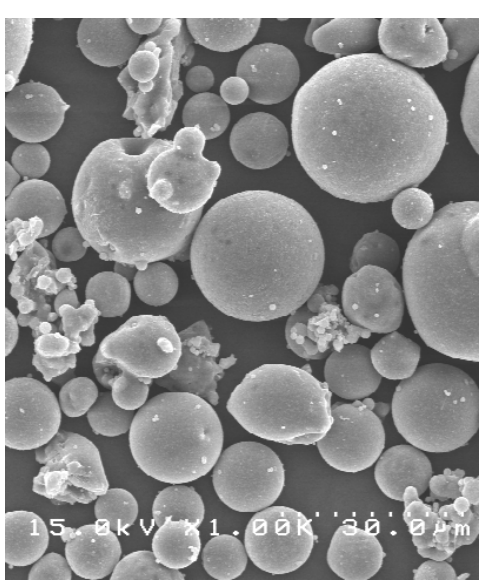

FA 4

Fig. (1). Scanning electron micrographs of fly ashes (1,500 times ).

Table 1. Chemical Analysis and Physical Characteristics of Fly Ashes

\begin{tabular}{|c|c|c|c|c|c|c|c|c|c|c|c|c|c|}
\hline & \multicolumn{7}{|c|}{ Chemical analysis } & \multicolumn{3}{|c|}{ Physical characteristics } & \multirow{3}{*}{$\begin{array}{c}\text { Percent } \\
\text { flow of } \\
\text { mortar } \\
(\%)\end{array}$} & \multirow{2}{*}{\multicolumn{2}{|c|}{$\begin{array}{c}\text { Strength } \\
\text { activity of } \\
\text { mortar (\%) }\end{array}$}} \\
\hline & \multirow[b]{2}{*}{$\begin{array}{l}\mathrm{SiO}_{2} \\
(\%)\end{array}$} & \multirow[b]{2}{*}{$\begin{array}{l}\mathrm{SO}_{3} \\
(\%)\end{array}$} & \multirow[b]{2}{*}{$\begin{array}{l}\mathrm{CaO} \\
(\%)\end{array}$} & \multirow[b]{2}{*}{$\begin{array}{c}\text { MgO } \\
(\%)\end{array}$} & \multirow[b]{2}{*}{$\begin{array}{c}\mathrm{Ka}_{2} \mathrm{O} \\
(\%)\end{array}$} & \multirow[b]{2}{*}{$\begin{array}{c}\mathrm{Na}_{2} \mathrm{O} \\
(\%)\end{array}$} & \multirow[b]{2}{*}{$\begin{array}{c}\text { Loss on } \\
\text { Ignition } \\
(\%)\end{array}$} & \multirow[b]{2}{*}{$\begin{array}{l}\text { Density } \\
\left(\mathrm{g} / \mathrm{cm}^{3}\right)\end{array}$} & \multicolumn{2}{|c|}{ Fineness } & & & \\
\hline & & & & & & & & & $\begin{array}{c}\text { Retained } \\
\text { on } 45 \mu \mathrm{m} \\
\text { sieve }(\%)\end{array}$ & $\begin{array}{c}\text { Specific } \\
\text { surface } \\
\text { area } \\
\left(\mathrm{cm}^{2} / \mathrm{g}\right)\end{array}$ & & $\begin{array}{c}28 \\
\text { days }\end{array}$ & $\begin{array}{c}91 \\
\text { days }\end{array}$ \\
\hline FA 1 & 60.0 & 0.2 & 1.2 & 1.8 & 0.7 & 0.0 & 0.9 & 2.39 & 0.1 & 5070 & 114 & 93 & 111 \\
\hline FA 2 & 59.9 & 0.2 & 1.3 & 0.6 & 0.7 & 0.0 & 0.9 & 2.29 & 7.1 & 3760 & 107 & 84 & 103 \\
\hline FA 4 & 57.4 & 0.2 & 1.6 & 0.5 & 0.7 & 0.0 & 1.7 & 2.15 & 12.5 & 1970 & 104 & 74 & 86 \\
\hline
\end{tabular}

Table 2. Physical Properties of Aggregates

\begin{tabular}{|c|c|c|c|c|c|c|}
\hline & Type of Aggregate & $\begin{array}{c}\text { Maximum Size } \\
(\mathbf{m m})\end{array}$ & $\begin{array}{c}\text { Density in Oven- } \\
\text { Dry Condition } \\
\left(\mathbf{k g} / \mathbf{m}^{\mathbf{3}}\right)\end{array}$ & $\begin{array}{c}\text { Absorption } \\
\mathbf{( \% )}\end{array}$ & $\begin{array}{c}\text { Bulk Density } \\
\left(\mathbf{k g} / \mathbf{m}^{\mathbf{3}}\right)\end{array}$ & $\begin{array}{c}\text { Fineness } \\
\mathbf{M o d u l}\end{array}$ \\
\hline \hline Coase aggregate & Crushed Sandstone & 20 & 2.70 & 0.51 & 1.58 & 6.69 \\
\hline Fine aggregate & River sand & 2.5 & 2.61 & 1.08 & 1.81 & 2.87 \\
\hline
\end{tabular}


Table 3. Mixture Proportion and Properties of Fresh and Hardened Concrete

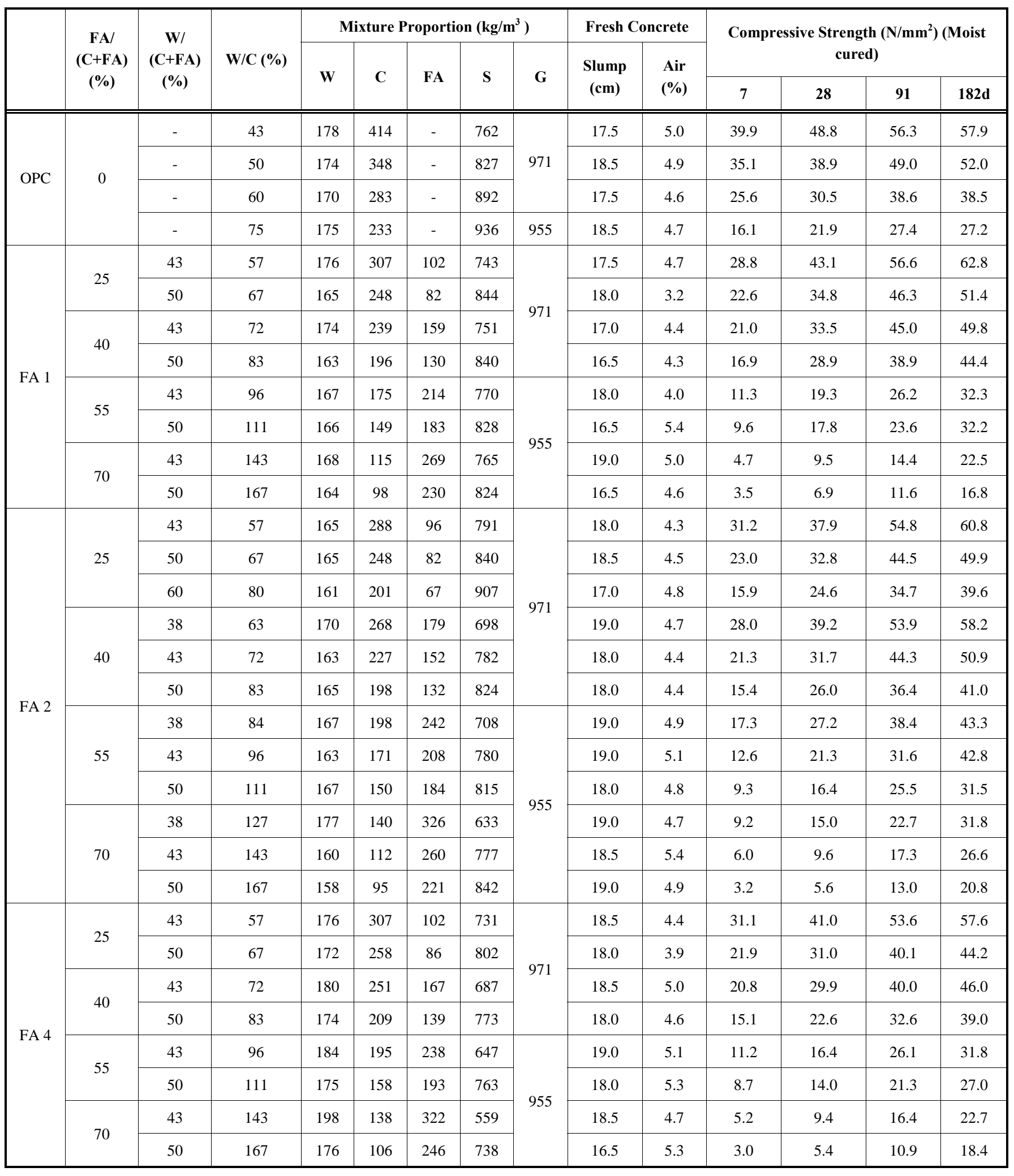

entraining agent dosage increases linearly with the fly ash replacement ratio, and that of FA1 is higher than that of FA2 and FA4, which is due to adsorption of air-entraining agent to particles of fly ash.

\section{EXPERMENTAL PROCEDURES}

\subsection{Fabrication and Curing of Test Specimens}

Cylinders, $100 \mathrm{~mm}$ in diameter and $200 \mathrm{~mm}$ in height, for compression tests are cast in metal moulds in 3 layers by 
tamping. The specimens are demoulded at 24 hours after casting, and are cured in water at $20^{\circ} \mathrm{C}$ till testing ages.

Prisms are used for drying shrinkage tests, accelerating carbonation tests, and freezing and thawing tests, the dimension of which is $100 \mathrm{~mm} \times 100 \mathrm{~mm} \times 400 \mathrm{~mm}$. Prisms are cast in two layers by tamping. They are demoulded at 24 hours after casting. Then, specimens for drying shrinkage test are cured in water at $20^{\circ} \mathrm{C}$ for 6 days. Those for accelerating carbonation test are cured in water at $20^{\circ} \mathrm{C}$ for 28 days and in air at $20^{\circ} \mathrm{C}$ for another 28 days. Prisms for freezing and thawing test are cured in water at $20^{\circ} \mathrm{C}$ until the age of 28 days.

\subsection{Test Method for Hardened Concrete}

\subsubsection{Compressive Strength Tests}

Cylinders were tested at the age of 1 week, 4 weeks, 8 weeks, 13 weeks and 26 weeks at wet condition.

\subsubsection{Drying Shrinkage Tests}

Prisms taken from water at 7 days, and were stored at $20^{\circ} \mathrm{C}$ and $60 \%$ R.H., and were measured for length change and weight loss for 26 weeks.

\subsubsection{Accelerating Carbonation Tests}

Prisms, moist cured for 28days and air dried for 28 days, are stored in accelerating carbonation chamber where it is in a condition of a temperature of $20^{\circ} \mathrm{C}$, relative humidity of $60 \%$, and the $\mathrm{CO}_{2}$ concentration of $5 \%$. Carbonation depth is determined by phenolephthalein test on cleaved surface.

\subsubsection{Freezing and Thawing Tests}

Prisms are subjected to Freezing and thawing cycles at the age of 28 days according to JIS A 1148-2001, similar to ASTM C 666-A. Durability factors are calculated after the freezing and thawing experiment is ended.

\section{TEST RESULTS AND DISCUSSIONS}

\subsection{Compressive Strength}

Table 3 shows the test results of fresh concrete and compressive strength tested on specimens cured in water at $20^{\circ} \mathrm{C}$.
Fig. (2) shows the strength development of fly ash concrete containing FA1, FA2 and FA4 fly ashes. Fig. (3) shows the effects of type and replacement ratio of fly ash on compressive strength at 13 weeks. Strength development of concrete containing FA4 is slower than those containing FA1 and FA2. When the fly ash replacement ratio increases the strength of fly ash concrete is reduced. This result has nothing to do with the type or particle size of fly ash. However, concrete samples with 25\% FA1 and FA2 replacing the same proportion of cement approximately show the same strength as that of OPC concrete at 13 weeks. Concrete containing FA4 shows slower strength development than that containing FA1 and FA2. As shown in Fig. (3), compressive strength at 13 weeks is found to be increased with the increase of specific surface area of fly ash.

Fig. (4) shows the relationship between binder water ratio and compressive strength of fly ash concrete containing FA2 in different replacement ratio at 13 weeks. Fig. (5) shows the relationship between cement water ratio and compressive strength of Portland cement concrete and concrete with fly ash at 13 weeks. Compressive strength is found to be increased with the increase of binder water ratio. Compressive strength of fly ash concrete at 13 weeks is almost in proportion to cement water ratio regardless of specific surface area of fly ash and replacement ratio.

\subsection{Drying Shrinkage}

Fig. (6) shows the effects of type and replacement ratio of fly ash on water content, drying shrinkage and weight loss of fly ash concrete $(\mathrm{W} /(\mathrm{C}+\mathrm{FA})=50 \%)$. Fig. (7) shows the effects of specific surface area of fly ash on drying shrinkage. Fly ash concrete shows a considerably lower drying shrinkage than OPC concrete. It depends on specific surface area with fly ash and replacement ratio. Concrete containing FA2 shows the smallest drying shrinkage and weight loss. Drying shrinkage of concrete with FA2 decreases with the increase of replacement ratio of fly ash. Drying shrinkage of OPC concrete increases with the increase of water content, and higher drying shrinkage of concrete with FA4 is in accordance with the higher water content.

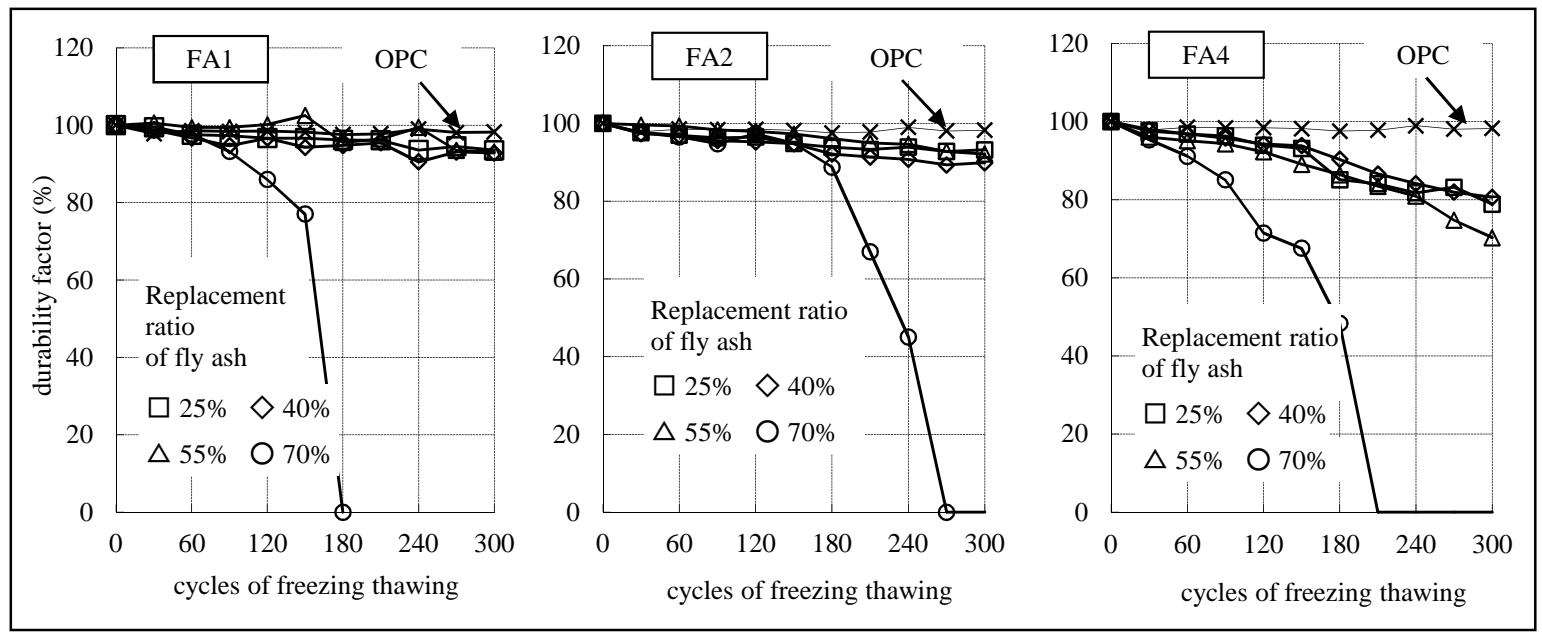

Fig. (2). Strength development of fly ash concrete $\left(W /(C+F A)=50 \%\right.$, cured in water at $\left.20^{\circ} \mathrm{C}\right)$. 


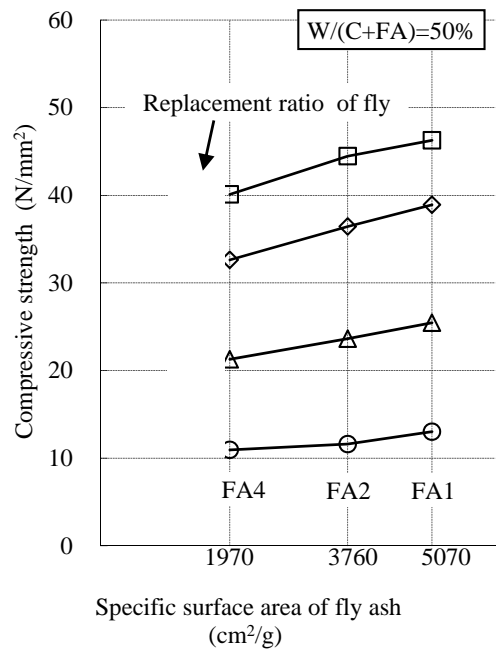

Fig.(3). Effect of type and replacement ratio of fly ash on compressive strengt at 13 weeks.

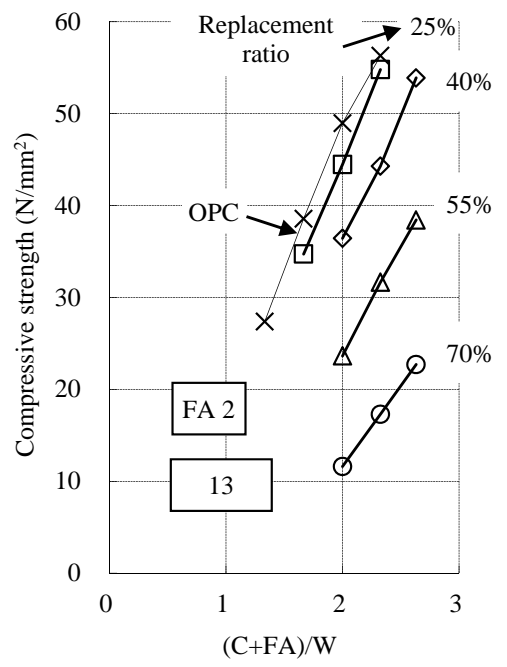

Fig. (4). Relationship between binder water ratio and compressive strength at 13 weeks.

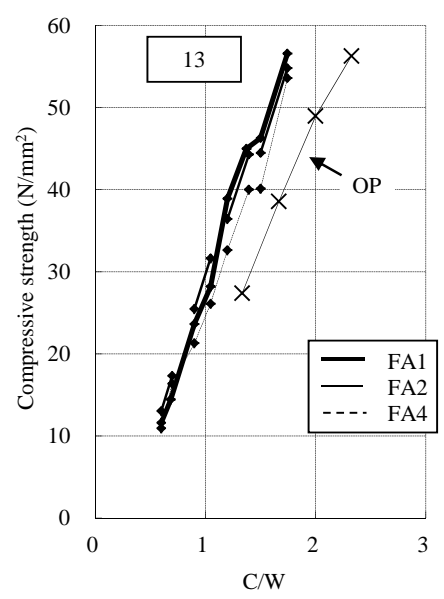

Fig. (5). Relationship between cement water ratio and compressive strength at 13 weeks.
Honda et al. [2] reported that drying shrinkage of concretecontaining fly ash with a specific surface area of 6000 $\mathrm{cm}^{2} / \mathrm{g}$ increased by about $20 \%$ in comparison with that containing fly ash with specific surface area of $3000 \mathrm{~cm}^{2} / \mathrm{g}$. In this paper, drying shrinkage of concrete containing FA1 increases by about $20 \% \sim 30 \%$ comparing with concrete containing FA2. However, higher drying shrinkage of concrete with FA1 in it can be due to carbonation shrinkage, as Neville A.M. discussed [3].

\subsection{Carbonation}

By means of conventional carbonation rate method, the carbonation depth is expressed by the equation (1) given below [4].

$$
C=A \sqrt{t}
$$

Where, C: carbonation depth, mm; t: elapsed time, week; and A: carbonation rate, $\mathrm{mm} / \sqrt{ }$ week.

Fig. (8) shows the test results of accelerated carbonation of OPC concrete and fly ash concrete, and Fig. (9) shows the effects of particle size and replacement ratio of fly ash on carbonation rate. Carbonation rate was found to be increased rapidly with the increase in replacement ratio of fly ash, and to be increased slightly with the increase in specific surface area of fly ash.

Fig. (10) shows the relationship between water binder ratio and carbonation rate of concrete containing FA2. Carbonation rate increases linearly with the increase of water binder ratio.

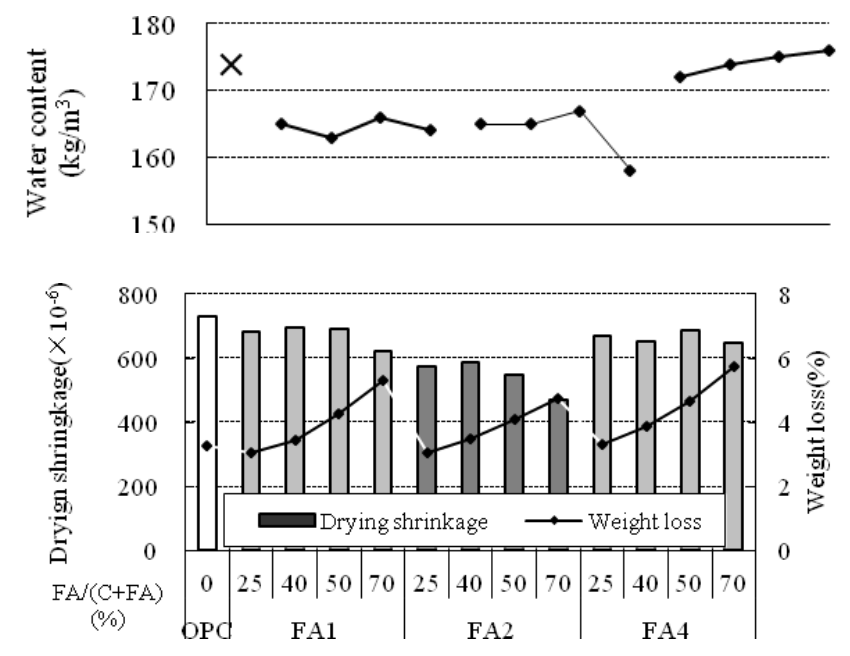

Fig. (6). Relationship among water content, drying shrinkage and weight loss at 13 weeks.

Fig. (11) shows the relationship between water cement ratio and carbonation rate. Relation between water cement ratio and carbonation rate is found to be the same of that of OPC concrete and concrete containing FA2 and FA4, while concrete containing FA1 shows slightly higher carbonation rate than the others with the same water binder ratio. Carbonation rate can be considered roughly proportional to water binder ratio regardless of particle size and replacement ratio of fly ash, and the same result was provided as Meyer, A. [5] and Wada et al. [6]. 


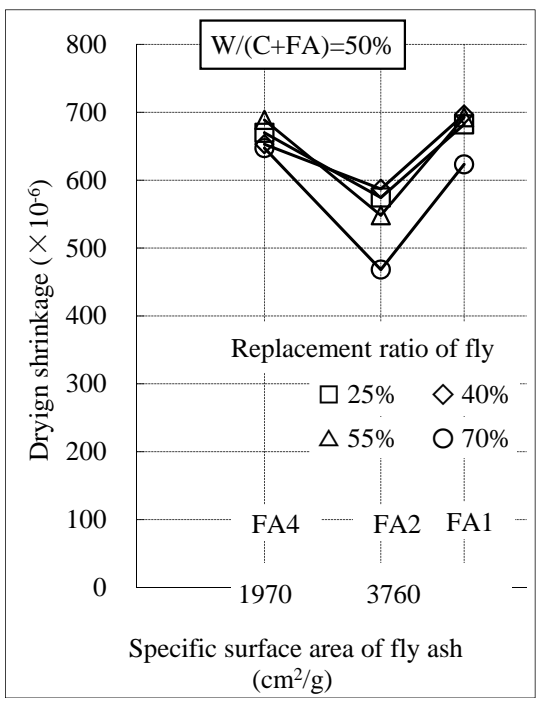

Fig. (7). Effect of specific surface area of fly ash on drying shrinkage at 13 weeks.

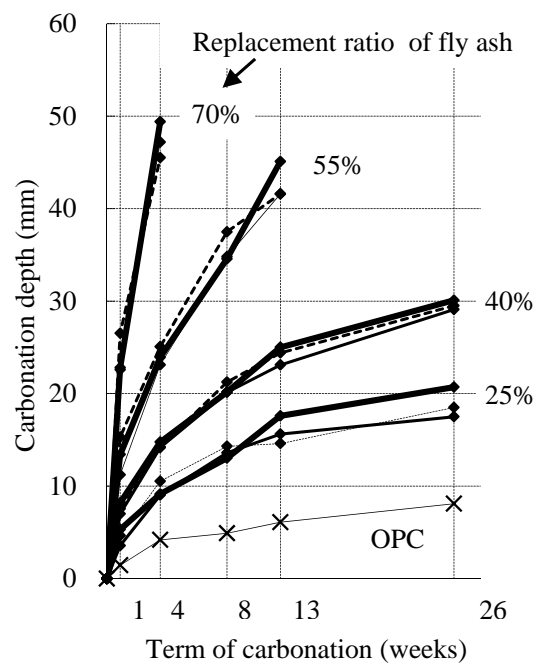

Fig. (8). Carbonation depth by accelerating carbonation(W/(C+FA) $=50 \%$, at $5 \% \mathrm{CO}_{2}$ ).

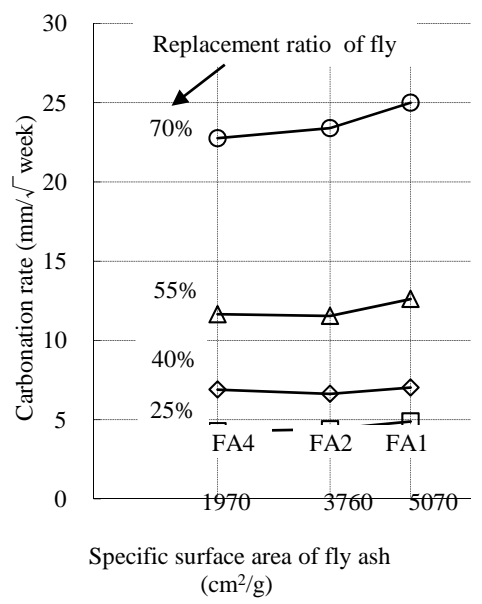

Fig. (9). Effect of specific surface area and replacement ratio of fly ash on carbonation rate.

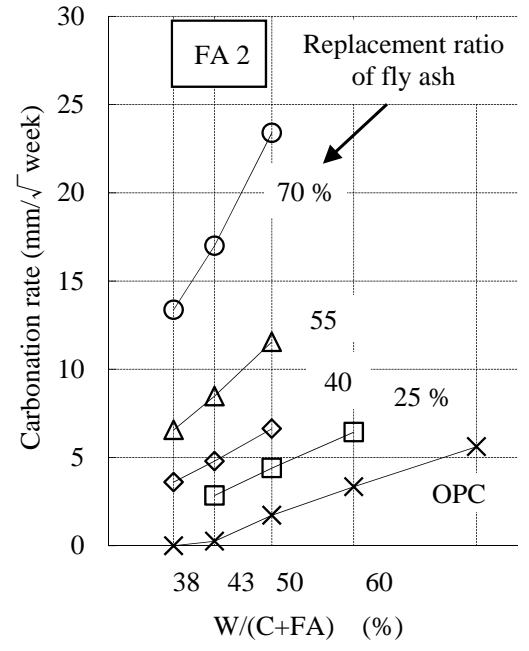

Fig. (10). Relationship between water binder ratio and carbonation rate.

Fig. (12) shows the relationship between compressive strength at 4 weeks and carbonation rate. Carbonation rate of concrete with and without fly ashes in it decreases exponentially with the increase of compressive strength. Fly ash concrete shows greater carbonation rate than OPC concrete with the same compressive strength. The increase in carbonation rate of fly ash concrete is caused by higher specific surface area of fly ash.

Fig. (13) shows the relationship between fly ash content and carbonation rate. Carbonation rate increases exponentially with the increase of fly ash content. The increase in carbonation rate of fly ash concrete can attribute to hysteretic formation of $\mathrm{Ca}(\mathrm{OH})_{2}$ caused by the fewer cement content and the decrease in $\mathrm{Ca}(\mathrm{OH})_{2}$ caused by the consumption in the pozzolanic reaction with fly ash. Higher carbonation rate of concrete with FA1 in it also can be explained by the higher pozzolanicity of FA1 with finer particle size and higher strength activity, as Masuda, Y. \& et.al. discussed [7].

\subsection{Resistance of Freezing and Thawing}

Fig. (14) shows the durability factor of air-entrained concrete containing OPC, FA1, FA2 and FA4 after 300 cycles of freezing and thawing. Durability factors of concrete with FA1 and FA2 replacing cement by $25 \%$ to $55 \%$ are higher than $80 \%$ of that of OPC concrete, while that of concrete with FA4 is less than $80 \%$ after 300 cycles. Concrete with FA replacing $70 \%$ cement is not durable and severely damaged by less than 300 cycles regardless of the type of fly ash or specific surface area.

\section{CONCLUSIONS}

Following conclusions are drawn from the experimental study on influences of type and replacement ratio of fly ash on strength and durability of concrete.

(1) Compressive strength increases with the increase in specific surface area of fly ash, strength development becomes slower with the increase of replacement ratio of fly ash. 


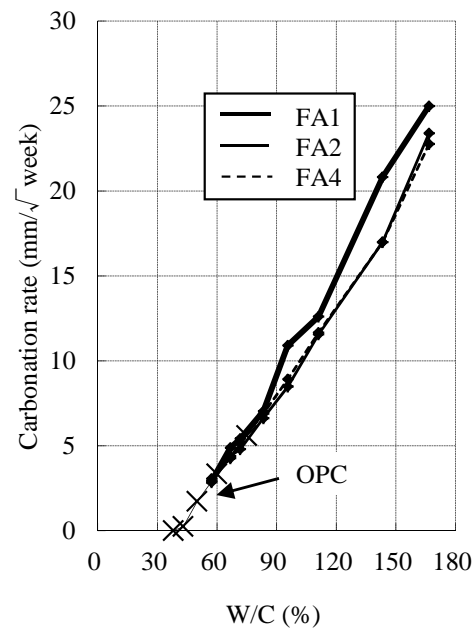

Fig. (11). Relationship between water cement ratio and carbonation rate

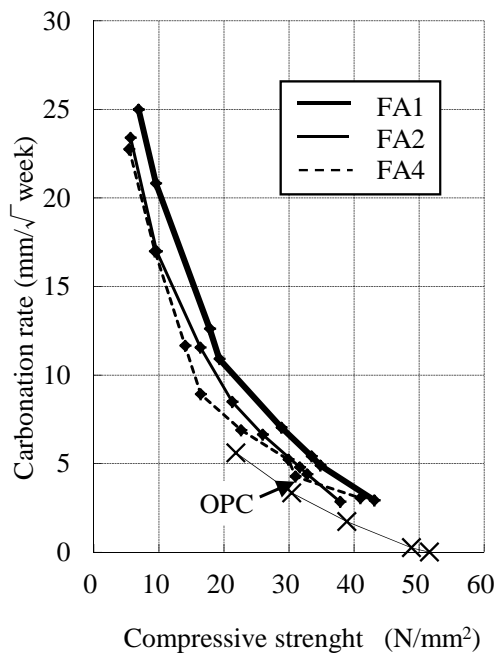

Fig. (12). Relationship between compressive strength at 4 weeks and carbonation rate

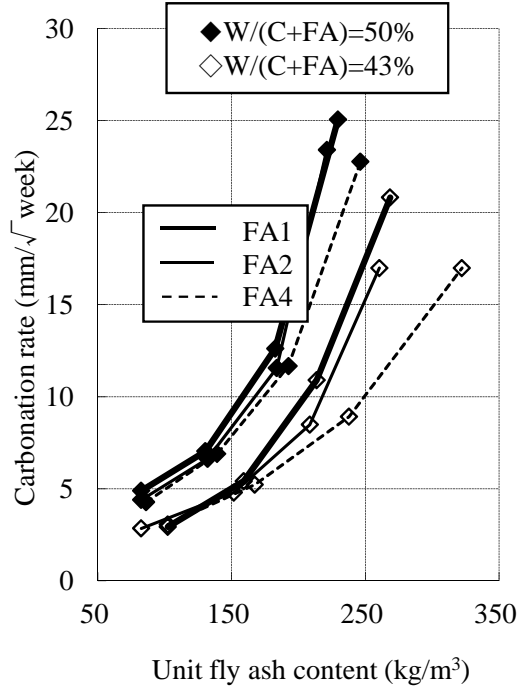

Fig. (13). Relationship between fly ash contentt and carbonation rate
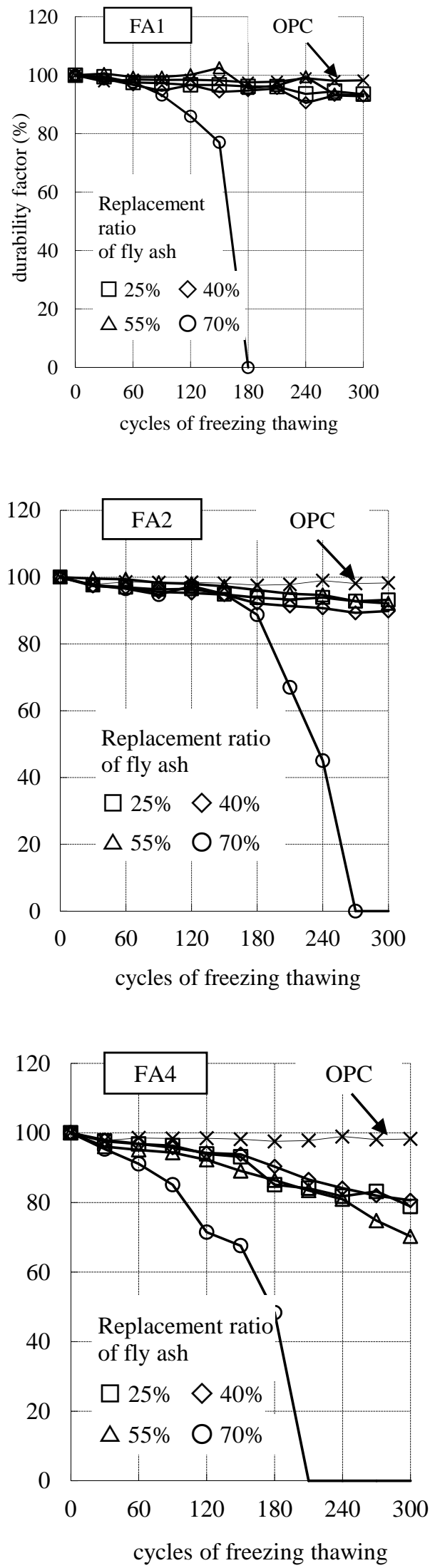

Fig. (14). Durability factor of concrete containing OPC, FA1, FA2 and FA4 
(2) Drying shrinkage of concrete with FA1 and FA2 is smaller than OPC concrete and concrete with FA4, and a higher replacement ratio of fly ash lead to lower drying shrinkage.

(3) Concrete containing fly ash is more prone to be carbonated. A higher replacement ratio or higher content of fly ash in concrete leads to a higher carbonation rate. The increase in carbonation rate with the fly ash replacement may be attribute to the reduction of $\mathrm{Ca}(\mathrm{OH})_{2}$ formation caused by reduction of Portland cement and consumption of $\mathrm{Ca}(\mathrm{OH})_{2}$ in pozzolanic reaction of fly ash.

(4) Air-entraining concrete containing FA1 and FA2 fly ash replacing cement from $25 \%$ to $55 \%$ has better freezing and thawing resistance. Concrete with Fly ash replacing $70 \%$ cement is much less durable.

\section{CONFLICT OF INTEREST}

The author(s) confirm that this article content has no conflicts of interest.

\section{ACKNOWLEDGEMENTS}

This research is supported by the Basic Research Projects of Qingdao Municipal Science and Technology Plan (No. 10-3-4-5-1-jch).

\section{REFERENCES}

[1] H Quan, "The Effects of Change in Fineness of Fly Ash on Airentraining Concrete", The Open Civil Engineering Journal, vol. 5, pp. 124-131, 2011

[2] S. Honda, and Shiiba, "Several properties of concrete using highvolume fly ash", In: Proceedings of the Japan Concrete Institute, vol. 23, no. 2, pp.127-132, 2001 (in Japanese)

[3] A, Neville, "Properties of concrete Longman Scientific \& Technical Harlow, Essex UK, $3^{\text {rd }}$ ed. Wiley: NY, 1981, pp.391-395.

[4] M, Hamada. "Carbonation of Concrete and Corrosion of Reinforcing Steel", In: Proceedings of the Cement Association of Japan, Cement \& Concrete, no.272, pp.2-18, Oct. 1969

[5] A, Meyer. "Investigation on the carbonation of concrete", In: Proceedings of 5th Int.Symp. on Chemistry of Cement, Part 3, pp.394401, 1968

[6] S, Wada. Abe, M., Yanagi, K. \& Fujita, K. "Experimental Study on Carbonation", Watertightness and Salt Interruption of Fly Ash Concrete, Proceedings of the Japan Concrete Institute, vol.20, no.2, 1998, pp.121-126. (in Japanese)

[7] Y, Masuda. \& Tanano, H., "Prediction model for progress of concrete carbonation”, In: Proceedings of Durability of Building Material and Components, pp.1152-1161, 1993.

Received: November 09, 2012

Revised: November 09, 2012

Accepted: January 03, 2013

(c) Quan and Kasami; Licensee Bentham Open.

This is an open access article licensed under the terms of the Creative Commons Attribution Non-Commercial License (http://creativecommons.org/licenses/ by-nc/3.0/) which permits unrestricted, non-commercial use, distribution and reproduction in any medium, provided the work is properly cited. 